\title{
ЕМОЦІЇ В СТРУКТУРІ ХОРЕОГРАФІЧНОГО ТЕКСТУ
}

\author{
Чілікіна Наталія Олександрівна, \\ https://orcid.org/ 0000-0003-3571-0566 \\ кандидат мистецтвознавства, викладач, \\ Наньчанський державний університет, \\ Китайська народна республіка, \\ natabzQukr.net
}

Стаття присвячена позначенню емоцій у структурі хореографічного тексту сучасного хореографічного мистецтва, що $є$ проблемою теорії танцю в її безпосередньому зв’язку із психологією, а також актуальною в контексті когнітивного підходу з характерними міждисциплінарними порівняннями. Досліджується позначення емоцій у створенні образної системи та композиційно-текстової структури, а також зв’язок із різними видами інформації, закладеними в хореографічному тексті. Метою дослідження $є$ з'ясування позначення емоцій та їхньої вагомості у структурі хореографічного тексту сучасного хореографічного твору. Методологія. Звернення до інтегральних функцій наукового дискурсу визначає сьогодні підхід до сучасного хореографічного мистецтва. Тож у дослідженні використовується когнітивний підхід до рішення поставленого завдання з характерними міждисциплінарними порівняннями у вивченні спостережуваних явищ, що дає змогу всебічно висвітлити об’єкт дослідження з погляду різних когнітивних тлумачень. Наукова новизна. У цій роботі значно розширені дослідницькі можливості аналітики сучасного хореографічного мистецтва за допомогою використання інтегральних складників. Висновки. Стверджується, що в сучасних дослідженнях хореографічного мистецтва доповнюються концептуальні основи. Позначення емоцій у структурі хореографічного тексту сприяє проникненню до внутрішнього світу героїв, опису їхного суб’єктивного переживання, заглибленню пізнання людської психіки, а значить - віддзеркаленню життєвих явищ. З’ясовано, що емоції, які виражені в хореографічному тексті, пов’язані з певним способом бачення балетмейстером простору його твору та з естетичною функцією художнього тексту. Доведено, що все це в цілому розкриває світогляд творця хореографічного тексту, впливає на відчуття й думки глядачів, а також на форму існування культури в певну історичну епоху.

Ключові слова: хореографія; емоція; хореографічний текст; комунікація; прагматичний потенціал.

\section{ЭМОЦИИ В СТРУКТУРЕ ХОРЕОГРАФИЧЕСКОГО ТЕКСТА}

\footnotetext{
Чиликина Наталия Александровна, https://orcid.org/ 0000-0003-3571-0566 кандидат искусствоведения, преподаватель Наньчанский государственный университет, Китайская народная республіка, natabzQuukr.net
}

Статья посвящена обозначению эмоций в структуре хореографического текста современного хореографического искусства, что является проблемой теории танца в ее непосредственной связи с психологией, а также актуальной в контексте когни-

\section{EMOTIONS IN THE STRUCTURE OF THE CHOREOGRAPHIC TEXT}

\author{
Nataliia Chilikina, \\ https://orcid.org/ 0000-0003-3571-0566 \\ Ph.D., Teacher of the Nanchang \\ State University, \\ Chinese People's Republic, \\ natabzQukr.net
}

The article is devoted to the designation of emotions in the structure of choreographic text of modern choreographic art, which is the problem of the theory of dance in its direct connection with psychology, as well as relevant in the context of a cognitive ap- 
тивного подхода с характерными междисциплинарными сравнениями. Исследуется обозначения эмоций в создании образной системы и композиционно-текстовой структуры, а также связь с различными видами информации, заложенными в хореографическом тексте. Целью исследования является выяснение обозначения эмоций и их значимости в структуре хореографического текста современного хореографического произведения. Методология. Обращение к интегральным функциям научного дискурса определяет сегодня подход к современному хореографическому искусству. Поэтому в исследовании используется когнитивный подход к решению поставленной задачи с характерными междисциплинарными сравнениями в изучении наблюдаемых явлений, что позволяет всесторонне осветить объект исследования с точки зрения различных когнитивных трактовок. Научная новизна. В данной работе значительно расширены исследовательские возможности аналитики современного хореографического искусства посредством использования интегральных составляющих. Выводы. Утверждается, что в современных исследованиях хореографического искусства дополняются концептуальные основы. Обозначения эмоций в структуре хореографического текста способствует проникновению во внутренний мир героев, описанию их субъективного переживания, углублению познания человеческой психики, а значит - отражению жизненных явлений. Выяснено, что эмоции, выраженные в хореографическом тексте, связанны с определенным способом видения балетмейстером пространства его произведения и с эстетической функцией художественного текста. Доказано, что все это в целом раскрывает мировоззрение создателя хореографического текста, влияет на чувства и мысли зрителей, а также и на форму существования культуры в определенную историческую эпоху.

Ключевые слова: хореография; эмоции; хореографический текс; коммуникация; прагматический потенциал. proach with characteristic interdisciplinary comparisons. The notations of emotions in the creation of the imaginative system and the compositional and textual structure, as well as the connection with various types of information embedded in the choreographic text, are investigated. Purpose of research is the designation of emotions and their significance in the structure of the choreographic text of a modern choreographic work. Methodology. Appealing to the integral functions of scientific discourse today distinguishes the approach to the modern choreographic art. Therefore, the study uses a cognitive approach to the problem solving with the distinctive interdisciplinary comparisons in the study of the observed phenomena. It allows us to illuminate the object of study comprehensively from the point of view of various cognitive interpretations. Scientific novelty. In this paper, the research capabilities of the modern choreographic art analytics are significantly expanded through the application of integral components. Conclusions. In this article it is argued that in contemporary studies of choreographic art, the conceptual foundations are supplemented. It is determined that the designation of emotions in the structure of the choreographic text contributes to penetration into the inner world of the heroes, description of their subjective experience, deepening of the human psyche knowledge, and, therefore, reflection of life events. It has been found out that the emotions, expressed in the choreographic text, are connected with a certain way of the choreographer vision of his work space and with the aesthetic function of an artistic text. It has been proved that all this in general reveals the world view of the creator of the choreographic text, affects the feelings and thoughts of the spectators, as well as the form of culture existence in a certain historical epoch.

Key words: choreography; emotion; choreographic text; communication; pragmatic potential. 
Актуальність теми дослідження. Зі становленням науки хореології значно розширилося наукове поле досліджень танцю, змінився його інструментарій і методологія. Нині важливою та мало вивченою проблемою теорії танцю $€$ дослідження емоцій у їх безпосередньому зв’язку із психологією. Актуальним $€$ і когнітивний підхід до вирішення поставленого завдання з характерними міждисциплінарними порівняннями у вивченні спостережуваних явищ, що передбачає всебічне висвітлення об’єкта дослідження з погляду різних когнітивних тлумачень. У цьому ж сенсі простежується позначення емоцій у створенні образної системи та композиційно-текстової структури, а також зв'язок із різними видами інформації, закладеними в хореографічному тексті.

Аналіз останніх досліджень та публікацій. К. Юнг охопив у своїх працях широкий спектр філософсько-психологічної проблематики - від традиційних для психоаналізу питань терапії нервово-психічних розладів до глобальних проблем існування людини в суспільстві, які розглядалися ним крізь призму власних уявлень про індивідуальну й колективну психіку та вчення про архетипи. Своїми ідеями психоаналітик справив значний вплив не тільки на психіатрію і психологію, а й на антропологію, етнологію, культурологію, порівняльну історію, релігії, педагогіку, літературу. Становлення сучасної науки хореології також визначається значним впливом робіт К. Юнга, а також сучасними дослідженнями в галузі психодіагностики (Щокін, 2011) та психології балету (Соковікова, 2006).

Творчість російських і західних балетмейстерів викликає наукову увагу російського мистецтвознавця Н. Зозуліної (2005) та білоруської дослідниці танцю Ю. Чурко (1999), але емоції розглядаються в них як ознаки специфічного творчого пошуку балетмейстерів, а не як структурний елемент композиційної побудови.

У вітчизняному мистецтвознавстві проблемам хореології присвячені наукові роботи дослідника О. Чепалова (2004; 2007), у яких подані принципові засади цієї науки, а проблематика емоційного складника розглядається в контексті образної системи всього хореографічного твору. Отже, відсутність досліджень емоцій в означеному контексті є суттєвим недоліком у теорії танцю.

Метою дослідження $є$ 3'ясування позначення емоцій та їхньої вагомості у структурі хореографічного тексту сучасного хореографічного твору.

Виклад основного матеріалу. Відповідно до свого комунікативного наміру сучасний хореограф відбирає для передавання сенсу елементи, що мають необхідне наочно-логічне, коннотативне, оцінне значення, внаслідок чого вони набувають певного прагматичного потенціалу та можливості справляти комунікативне враження на глядача.

Це безпосередньо пов'язано з характером протікання емоційних процесів, які в танці виявляються і зовні (а отже, доступні спостереженню), і внутрішньо (тобто не виявляються зовні, а відчуваються самою людиною, підживлюючи зовнішню симптоматику). Емоції в певних проявах хореографічного задуму ідентифікують усі зовнішні емоційні реакції: психофізіологічні симптоми (вегетативні та рухові реакції), комунікативні та некомунікативні кінеми (міміка, жесті, пози). Цей процес нерозривно пов'язаний із сукупністю всіх розумових, ментальних і психічних процесів сприйняття. У ході практичної діяльності людина має справу не безпосередньо 3 навколишнім світом, а 3 когнітивними картинами (моделями) світу, який представлений людині через призму його культури та ментальності. Відтак чітко простежується зв’язок мови з ментальними об'єктами, у яких зафіксовані результати віддзеркалення зовнішнього світу в свідомості певної особи. 
Проблема визначення прагматичного потенціалу позначень емоцій у структурі хореографічного тексту вимагає розгляду та поєднання в одному дослідженні безлічі приватних проблем, таких як: емоції та їх позначення в пластиці; когнітивний процес розпізнавання образів (знаків), що характеризують ту або ту емоцію; прагматична характеристика художньої комунікації. Вивчення цих процесів є особливо актуальним для хореографічного тексту, оскільки в центрі балету або іншого танцювального твору знаходиться людина $з$ її вчинками, ставленням до інших осіб, думками, почуттями та особливостями пластичних інтонацій.

При цьому очевидно, що особливості позначень емоцій і в статиці, і в динаміці з'ясовуються тоді, коли глядач намагається розкрити причинну сторону процесу, встановити сукупність чинників, що заставляють об’єкт змінюватися в різних культурно-історичних умовах, що в цілому засвідчує широкий спектр завдань у теоретичних дослідженнях танцю та ситуаціях міжособистісного спілкування.

Сучасний хореограф обирає способи мовного вираження хореографічного тексту i, відповідно до свого комунікативного наміру, використовує для передавання інформації мовні одиниці, що мають наочно-логічне й коннотативне значення, встановлюючи між ними необхідні смислові зв’язки. В результаті створений хореографічний текст, аналогічно граматичним формам вербальної мови, набуває певного прагматичного потенціалу, можливості справити комунікативне враження на глядача (спостерігача). При цьому він визначається змістом і формою повідомлення та існує немов би незалежно від творця тексту.

Трапляється, що прагматика тексту не повністю збігається з комунікативним наміром хореографа (виразив не так, як хотів, або не те, що хотів). Але тією мірою, якою прагматика певного тексту залежить від інформації та способу її передавання, вона є об’єктивною суттю, доступною для розпізнавання та аналізу. Це першочергово стосується невербальних компонентів експресії в танці, що розглядається в контексті комунікативного акту. Їх, своєю чергою, можна розподілити за групами:

1) емоційний стан героя в статиці (пантоміма, яку складають міміка, жести, пози);

2) пантоміма, що переходить у танець (дієвий танець, згідно із традиціями Новера), яка передбачає комунікативні та некомунікативні рухи (залежно від намірів персонажа та його схильності до рефлексії як процесу самопізнання внутрішніх психічних актів і станів);

3) експресія в контексті гендерної проблематики (відповідність рухів певним стандартам фемінності та маскулінності), гендерні аспекти позначення емоцій, що базуються на конвенції емоційних станів чоловіків та жінок у художній культурі XXI ст. та попередніх часів, стаючи культурно й історично обумовленими концептами.

Визначена перша група невербальних компонентів $є$ найпоширенішою у використанні, хоча й найбільш обмеженою в контексті художньої комунікації.

Друга група є актуальною для сучасних хореографів, що віддають перевагу танцювальним виставам. Яскравим прикладом може слугувати творчість Дж. Ноймайєра, який вважає, що танцю потрібні стани, зумовлені реакцією на реальну ситуацію, у якій знаходяться герої і яка народжує емоційні висловлення. Цей підхід підтверджується міркуваннями самого Ноймайєра про Шекспіра: «Його п’єси написані про таке, що лежить понад словами. Це робить його видатним автором не тільки п’єс, а й балетів» (Зозулина, 2005, с. 15).

Розглядаючи третю групу, варто звернутися до творчості Піни Бауш. Наприклад, у виставі «Кафе Мюллер»: «всі гріхи людства злилися в один: чоловіча хіть. 
Це вона калічить і зводить Анну (партія, яку колись виконувала сама Бауш) до стану загнаного звіра» (Чурко, 1999, с. 154).

Невербальні компоненти в танці як комунікативному акті можна розглядати і в інших аспектах (наприклад, у зв’язку з вибором певної смислової наповненості загального емоційного стану). При цьому вирішальне значення має аналіз тих певних умов, у яких означена номінація набуває «прагматичного навантаження», досягаючи ефекту невербального спілкування.

Для позначення емоцій характерне метафоричне перенесення. Метафоризація, як спосіб переосмислення на основі схожості або аналогії ознак в понятійному віддзеркаленні об'єкта, що позначається, і його пластичного переосмислення, $\epsilon$ своєрідною «картиною світу», яка неоднакова в носіїв різних культур або однієї та тієї ж культури в окремі історичні періоди. У створенні метафоричного тексту хореограф базується на загальноприйнятих асоціаціях або стереотипах, але авторська метафора в танці також, як і в інших видах творчої діяльності, визначається культурними нормами, соціальною ситуацією, прагматичною, когнітивною та емоційною спрямованістю.

При цьому виникає так звана «наївна картина світу», як її називають лінгвісти. Це різновид концептуальної картини світу в результаті практичного пізнання дійсності, що має етнічну (національну) специфіку і своєрідне вираження в лексичному складі мови. Вона істотно відрізняється від наукової, чисто логічної картини світу, і тим зближується за сенсом із хореографічним твором, побудованим на ланцюжку метафор у їхніх пластичних проявах і переосмисленні реальної картини людського існування у світовому просторі.

Наприклад, твори Ноймайєра сприймаються насамперед як постановки, де хореографія, що є основним засобом виразності, виступає і матеріалом для вираження психологічного життя людини, людських стосунків. Ноймайєр «експериментує 3 новими видами сюжетних балетів або балетних сюжетів, які важко висловити вербально, але які очевидно візуальні, бо уособлюють суміш індивідуальних настроїв, емоційних взаємодій, душевних поривань та бажань героїв, що виходять за межі причин виникнення та логіки розвитку цих почуттів» (Зозулина, 2005, с. 16).

Балет Дж. Ноймайєра «Ніжинський» - це грандіозна хореографічна фреска-диптих з величезною кількістю учасників, присвячений трагічній особистості; це монографічний балет, поставлений як «романне» полотно з видом на епоху - епоху срібного століття, дягилевських сезонів і Першої світової війни. Але як і будь-який балет, що позначений здатністю узагальнювати конкретний час, місце та дії героїв в ім’я вічної проблематики людської душі, «Ніжинський» звернений не до історії, а до сучасного дня, він змушує глядача перестраждати те, як колись жила людина, наче вона сучасник, що поруч з нами. Ноймайєр, насамперед, психолог, що намагається хореографічними засобами відповісти на хвилюючі питання людського буття; він нагороджує своїх героїв багатим внутрішнім світом, ставить перед ними складні психологічні завдання еволюції особистості, пошуків самого себе, зіштовхує ці мікрокосмоси один з одним і пропонує нам свою версію того, як може бути вирішена та чи інша життєва ситуація. Пластичні знахідки митця настільки точно й правдиво відображають емоційний стан людини, що в глядача виникає враження істинності його інтерпретації як єдино можливого рішення (Чепалов, 2007, с. 234).

Кульмінаційна зона балетної драми здається нескінченною за протяжністю. Цей важливий драматургічний епізод за стилем пластично нагадує психоаналіз емоційного життя героя, який хореограф-психоаналітик намагається зафіксувати 
й передати зі своєрідною «медичною точністю». Двадцять хвилин безперервної напруги представляють справжню «анатомію вбивства». Ноймайєр не щадить глядача, пропонуючи йому урок моральності і стоїцизму. Перед нами картина фізичних і душевних мук героя. Хореограф ставить майже клінічну картину його духовної агонії.

Позначення емоції може бути вербалізованим, оскільки є породженням мовної та розумової діяльності та використовує в словосполуках дієслова руху й конкретної фізичної дії, особливо продуктивні в плані породження образного представлення емоцій. Переконливими в цьому сенсі $є$ пушкінські рядки, що описують танець знаменитої російської балерини А. Істоміної.

У науковій практиці набагато точнішим за суттю це позначення стає, коли знаходиться в повній відповідності з уявленнями про те, що повинна відчувати людина в певному емоційному стані і як це має виявлятися зовні. А це можливо виразити лише театральному акторові або танцівникові. Отже, позначення емоцій у художньому тексті залежить не лише від реалій об’єктивного життя, але й людського уявлення про них. У емоційних па́тернах відбиті особливості попередніх століть, людських відносин із довкіллям, тваринним світом. Відображуючи явища та процеси навколишньої дійсності, позначення емоцій фіксують розвиток асоціативних зв'язків і художньої уяви в носіїв різних мов, які в хореографічному тексті стають метафоричними й узагальнюючими.

Згадуючи, наприклад, творчі прийоми М. Ека в балеті «Жизель» сучасна дослідниця Ю. Чурко підкреслює: «з однакових рухів Ек створює танець-провокацію, танець-божевілля, танець-володіння, він працює із пластичним матеріалом як хореограф, а не як концептуаліст. Зокрема, у дуеті Жізелі та Альберта першої дії естет «розмовляє» із простуватою дівицею доступною їй пластичною мовою, але в той же час вабить її чимось новим, що не входить уїї танцювально-пластичний лексикон» (Чурко, 1999, с. 33).

Своєю чергою, художня мова балетмейстера-постановника входить у систему розпізнавання образів хореографічного спектаклю як образ авторський, не вилучний від характеристик персонажів і стильової єднальної художньої структури твору. Позначення емоцій знаходиться в прямій залежності від вибраного типа оповідальності та від того, емоційна перевага якого персонажа в творі описується - головного чи другорядного. Отже, створюється природний хід розвитку сюжету з доповненням його різними необхідними деталями, які допомагають проникнути у внутрішній світ героїв; заглиблюють пізнання людської психіки й тим самим художньою формою відбивають життєві явища, образи; передають суб'єктивну оцінку автора, оповідача й персонажів, а також імпліцитний сенс, прихований у художньому творі, який виникає в читача при сприйнятті тексту.

До того ж усі типи позначень емоцій здатні передавати в художньому тексті також і приховану, підтекстову інформацію. Для підтексту, що розуміється як особливий спосіб організації тексту, що веде до поглиблення або навіть зміни його семантичного й емоційно-психологічного змісту, необхідне знання всього тексту в цілому. Тобто можна вести мову про взаємозв'язок прагматичного потенціалу позначень емоцій із прагматичним потенціалом усього художнього тексту. Так простежується зв'язок позначень почуттів із емоційною оцінкою художнього твору, фоновими знаннями читача та підтекстом із емоційною й естетичною дією на останнього. В результаті формується весь комплекс знань про текст, що вивчається.

Наукова новизна. У цій роботі значно розширені дослідницькі можливості аналітики сучасного хореографічного мистецтва за допомогою використання інтегральних складників. 
Висновки. Підсумовуючи матеріал дослідження, варто зазначити, що позначення емоцій у структурі хореографічного тексту, доповнення необхідними деталями сприяє проникненню до внутрішнього світу героїв, опису їхнього суб'єктивного переживання, заглибленню пізнання людської психіки, а отже, віддзеркаленню життєвих явищ. Емоції, виражені в хореографічному тексті, пов'язані з певним способом бачення балетмейстером простору його твору та з естетичною функцією художнього тексту. Все це в цілому розкриває світогляд творця хореографічного тексту, впливає на відчуття й думки глядачів, а також на форму існування культури в певну історичну епоху.

\section{СПИСОК ПОСИЛАНЬ}

Зозулина, Н. (2005). Проблема интерпретации драматургии Шекспира в балетном театре Джона Ноймайера. "Ромео и Джульетта". (Автореферат диссертации кандидата искусствоведения). Санкт-Петербургская академия театрального искусства, Санкт-Петербург.

Соковикова, Н. (2006). Введение в психологию балета. Новосибирск: Сова.

Чепалов, О. (2004). Когнітивні аспекти хореографічної лексики. Культура України. Серія: Мистецтвознавство, 14, 109-115.

Чепалов, О. (2007). Хореографічний театр Західної Європи XX cm. [Монографія]. Харків: ХДАК.

Чурко, Ю. (1999). Линия, уходящая в бесконечность: Субъективные заметки о современной хореографии. Минск: Полымя.

Щекин, Г. (2011). Визуальная психодиагностика: познание людей по их внешности и поведению. Киев: Персонал.

Юнг, К., Франц, М.-Л., Хендерсон, Дж., Якоби, И., \& Яффе, А. (1998). Человек и его символы. (С. Сиренко, пер.). Москва: Серебряные нити.

\section{REFERENCES}

Chepalov, O. (2004). Kohnityvni aspekty khoreohrafichnoi leksyky [Cognitive aspects of choreographic vocabulary]. Kultura Ukrainy. Series: Mystetstvoznavstvo, 14, 109-115 [in Ukrainian].

Chepalov, O. (2007). Khoreohrafichnyi teatr Zakhidnoi Yevropy XX st. [Choreographic Theater of Western Europe of the twentieth century] [Monograph]. Kharkiv: KhDAK [in Ukrainian].

Churko, Yu. (1999). Liniya, uhodyaschaya v beskonechnost: Sub'ektivnyie zametki o sovremennoy horeografii [The line going to infinity: Subjective notes on modern choreography]. Minsk: Polyimya [in Russian].

Schekin, G. (2011). Vizualnaya psihodiagnostika: poznanie lyudey po ih vneshnosti i povedeniyu [Visual psychodiagnostics: knowledge of people by their appearance and behavior]. Kyiv: Personal [in Russian].

Sokovikova, N. (2006). Vvedenie v psihologiyu baleta [Introduction to the psychology of ballet]. Novosibirsk: Sova [in Russian].

Yung, K., Frants, M.-L., Henderson, Dzh., Yakobi, I., \& Yaffe, A. (1998). Chelovek i ego simvolyi [Man and his characters]. (S. Sirenko, Trans.). Moscow: Serebryanyie niti [in Russian].

Zozulina, N. (2005). Problema interpretatsii dramaturgii Shekspira v baletnom teatre Dzhona Noymayera. "Romeo i Dzhuletta" [The Problem of Interpreting Shakespeare's Dramaturgy at the John Neumayer Ballet Theater. "Romeo and Juliet"]. (Extended abstract of candidate's thesis). Saint-Petersburg Theatre Arts Academy, St. Petersburg [in Russian]. 